\title{
FYHE
}

The International J ournal of the First Year in Higher Education

ISSN: $1838-2959$

Volume5, Issue 2, pp. 45-55

August 2014

\section{Increasing the emotional engagement of first year mature-aged distance students: Interest and belonging}

Ella Kahu

Massey University, Wellington, New Zealand

\begin{abstract}
This research followed 19 mature-aged distance students through their first semester of undergraduate study. The analysis of interviews and video diaries presented in this paper focuses on two key elements of emotional engagement: interest and belonging. Findings highlight the importance of interest triggered by personal preferences and experiences. Interest led to enjoyment, increased behavioural engagement with greater time and effort expended, and improved cognitive engagement in terms of depth and breadth of learning. In contrast, there was less evidence of the social side of emotional engagement, belonging. Participants felt little connection to the university, but connecting with fellow students through face-to-face courses and online forums was important for some to reduce their sense of isolation. However, distance study was not for all. The findings highlight the need for staff to consider emotional engagement when designing and delivering the curriculum and when interacting with students, particularly in the all-important first year.
\end{abstract}

\section{Please cite this article as:}

Kahu, E. (2014). Increasing the emotional engagement of first year mature-aged distance students: Interest and belonging. The International Journal of the First Year in Higher Education, 5(2), 45-55. doi: $10.5204 /$ intifyhe.v5i2.231

This article has been peer reviewed and accepted for publication in Int J FYHE. Please see the Editorial Policies under the 'About' section of the Journal website for further information.

(C) Copyright of articles is retained by author/s. As an open access journal, articles are free to use, with proper attribution, in educational and other non-commercial settings. ISSN: 1838-2959 


\section{Introduction}

This paper examines the emotional engagement of a group of mature-aged (over 24 years) distance students in their first semester at a New Zealand university. Improvements in technology are leading to an increase in the distance delivery of tertiary education, which is particularly appealing to mature-aged students as it enables them to study alongside existing family and work commitments. In New Zealand, a third of all undergraduate degree students are over aged 24 and a third of those study by distance (Ministry of Education, 2013). The particular experiences of this growing population of students warrant separate study. In particular, emotional engagement is a critical but often overlooked aspect of learning and the transition to university is a particularly emotional time. This paper examines two elements of emotional engagement during students' first semester, interest and belonging, and explores their antecedents and consequences in this population.

\section{Student engagement and emotion}

Student engagement is recognised as an important meta-construct in education, linked to both student achievement and satisfaction (Trowler \& Trowler, 2010). It is also related to retention (Kuh, 2009) and so is a valuable lens through which to examine the transition to university, a time of high student attrition. There are, however, multiple definitions of student engagement. In higher education, the most widely used, as measured by the Australasian Survey of Student Engagement, focuses on student behaviour, the time and effort they put into their study (Australian Council for Educational Research, 2010). Less attention has been given to students'

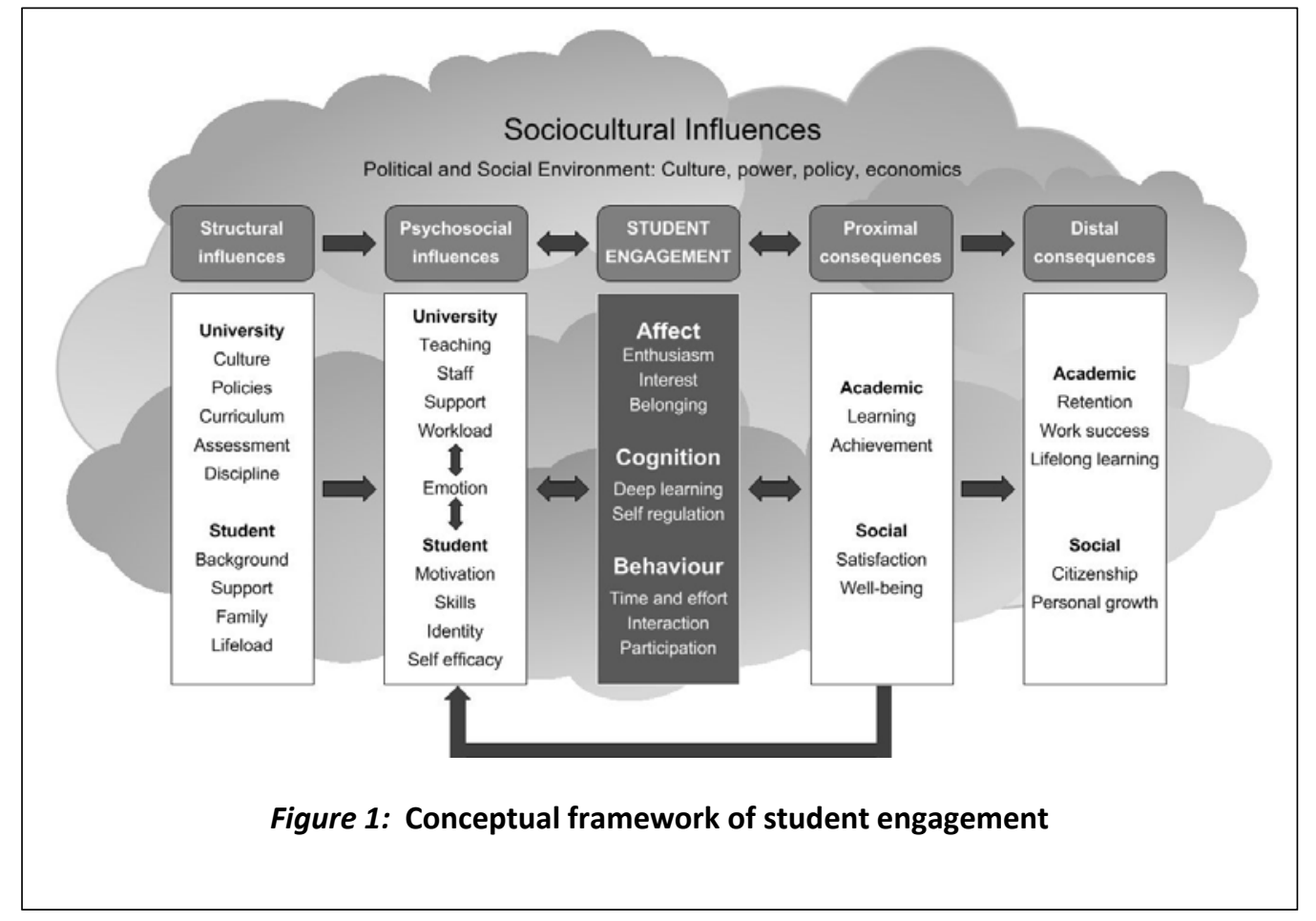

46 | The International J ournal of the First Year in Higher Education, 5(2) August, 2014 
emotional engagement despite a growing body of literature acknowledging the critical role that emotion plays in learning and in understanding the student experience (Dirkx, 2006; Linnenbrink, 2006). In particular, the transition to university is recognised as a time of considerable emotional volatility (Christie, Tett, Cree, Hounsell, \& McCune, 2008).

The current study uses a modified version of Kahu's (2013a, p. 766) conceptual framework of student engagement, which emphasises the role of emotion. This framework, depicted in Figure 1, draws together the diverse perspectives of student engagement evident in the literature. Student engagement is depicted as the student's emotional, behavioural, and cognitive connection to their study, influenced by a wide range of psychosocial and structural factors from both the university and the student. In addition, engagement is recognised as occurring within, and being influenced by, the wider sociocultural context.

This paper focuses specifically on students' emotional engagement. Paralleling Tinto's (1975) classic work on academic and social integration, emotional engagement has two primary elements: the students' interest in and connection with the course content, and the students' sense of belonging or connection to the institution, staff, and other students.

\section{Interest}

Interest is the link between a person and a task or topic (Ainley, 2006). It motivates learning, and research suggests that interested students expend more effort and retain more course content (Silvia, 2006). According to Pekrun and LinnenbrinkGarcia (2012), interest combined with a belief in one's competence for the task leads to enjoyment. Research with mature-aged students shows that interest in course content is one of their key motivations for studying (Leder \& Forgasz, 2004; Marandet \& Wainwright, 2009) and that one important source of that interest is their ability to link their learning with their work experience (Kahu, Stephens, Leach, \& Zepke, 2013).

\section{Belonging}

According to Thomas (2012), belonging can be defined as "students' subjective feelings of relatedness or connectedness" (p. 12); it encompasses feeling accepted, valued, and supported by the institution, staff, and other students. Social interaction is important for developing a sense of community, which is valuable for all students including distance students (Ke \& Xie, 2009; Rovai, 2002). Research with mature-aged students has often found a lack of belonging, with the students feeling they do not "fit" within the traditional university culture (Gallacher, Crossan, Field, \& Merrill, 2002; Johnson \& Watson, 2004). Despite this, studies show that older students interact more in the classroom (Kasworm, 2010; Wyatt, 2011) and the online equivalent, the discussion forum (DiBiase \& Kidwai, 2010; Hoskins \& Hooff, 2005). These interactions are more likely to be academic than social (Lundberg, 2003). There are however mixed findings as to the importance of social connections for mature-aged students who may have less desire and time for such activities (Christie, Munro, \& Wager, 2005; Wyatt, 2011).

The aim of this paper is to examine these two types of emotional engagement, interest and belonging, in a population of mature-aged distance students during their first semester as undergraduate students. As well as exploring the effects of emotional engagement, the analysis looks at the barriers and drivers of interest and 
belonging in order to make recommendations for practice.

\section{Method}

The study is located within a critical realist paradigm which recognises that social phenomena such as the student experience are open and complex, as depicted in the conceptual framework above, and so best studied by interpretive methods that emphasise meaning and processes (Sayer, 2000). The goal of such research is explanation rather than quantification - to observe the student experience and to propose hypothetical mechanisms that explain what we have observed (Mingers, 2004). The research therefore has an in depth qualitative design. In addition, the transition to university has been described as "a real roller coaster of confidence and emotions" (Christie et al., 2008, p. 573) and therefore the students were followed throughout their first semester in order to capture the dynamic nature of their engagement.

\section{Participants}

The 19 participants were first year undergraduate distance students from around New Zealand. The students' ages ranged from 25-59, there were 15 females and 4 males, and they were diverse in terms of family structure, geographical location, and occupation. Fifteen were European New Zealanders, five Maori, two Asian, and one was from the Cook Islands (some participants recorded multiple ethnicities). The students were enrolled in a variety of disciplines including business studies, arts, science, and education; four were enrolled full time, twelve approximately half time, and three were enrolled in just one course.
The courses $^{1}$ had some print-based materials along with online components including access to discussion forums. Some courses also included optional two to five day campus-based sessions.

\section{Data collection and analysis}

Semi-structured family interviews were held before the semester started, focussing on expectations, motivation, and preparation. In addition, the students recorded diaries approximately weekly: 17 by video and two by email. The students talked about their study in terms of what they were thinking, doing, and feeling, and what they felt influenced their engagement with their study. To encourage deeper reflection, the author listened to each diary and responded by email with further prompts. Four students withdrew from their study early in the semester and their follow up interviews were conducted by telephone. At the end of the semester, follow up family interviews were conducted with all except two of the remaining participants who were unavailable.

The interviews and diaries were fully transcribed and then analysed thematically using the interpretive approach outlined by Braun and Clarke (2006). This analysis method, following coding of the data, identified themes from surface meaning, taking language as a simple and neutral expression of people's experiences. It aligns well with critical realism, as it enables an understanding of how the individual experiences their world as well as the impact of the broader social context. All emotions were coded, along with aspects of the context, antecedents, and consequences. This paper reports specifically on the

\footnotetext{
1 This refers to a semester-long teaching activity and is synonymous with "unit"“, subject" or "course". The terms "paper" and "course" are used interchangeably throughout.
} 
findings related to the students' interest and belonging.

\section{Findings}

\section{Interest}

The importance of the first type of emotional engagement shown in the framework, interest, was clear in the students' talk. Many of them were strongly motivated by a love of learning that was expressed through a metaphor of knowledge as nourishment for the mind: "I like to learn... I think it keeps your brain alive" (Charlotte) ${ }^{2}$. As well as this generic desire to learn, the students' interest was triggered by connections between course content and their past work experiences, the future application of knowledge, their personal lives, and their particular passions as the following quotes illustrate:

Vee: I truly enjoy reading articles that I researched. I can easily relate to it based on my previous work experience as compared to the boring theories in the textbook.

Maria: Yeah like I really like the content, and the idea of where I can take it, I think I'm getting excited about the possibilities.

Samantha: It definitely is something that I use within my life and with bringing up the children, and I find that subject to be really interesting.

The students' interest and enjoyment in learning motivated them. When they were interested, they wanted to do better and were prepared to work harder: "I'm really, really trying hard to do well because I'm enjoying the paper and I'm enjoying the ideas" (Maria). Importantly, as well as increasing their behavioural engagement, interest increased their cognitive engagement - they found it easier to understand and learn the content. Daniel explains the difference:

Daniel: Mind you, the other paper I'm not that interested in, so I'm just doing it as it comes along and everything like that. But the plague one I tend to read more and read through it faster and absorb a lot more I think.

This power of interest to spark a positive emotional, behavioural, and cognitive upward spiral is clearly illustrated by Melissa:

Melissa: I am absolutely loving my study... I'll be up early, my head will be in that computer and I'll be head down and bum up and rather than that being a chore, I just love it. My brain just needs feeding (laughs). The more I learn, the more I want to learn. It's like I'm addicted to it almost.

Course design and content were critical influences on interest. For instance, courses that students chose to do, or that offered opportunities for choice of sub-topics or assessments, enabled them to follow their interests and therefore experience that positive spiral. On the other hand, compulsory courses and topics that did not interest the students often led to boredom and frustration. Boredom was consistently linked with lower behavioural and cognitive engagement. Bored students procrastinated more, studied less, and, importantly, found the learning more difficult:

Lexi: The moral stuff was just as boring as cardboard and it was just really hard to connect to.

Daniel: Oh my god, I just cannot absorb this information. I'm just not interested.

2 Participants were allocated a pseudonym. 
Even if a topic was inherently interesting to the student, course design factors such as workload or poor organisation could stifle a student's emotional engagement with the course:

Maria: It's funny because I really thought that particular paper with the high workload was going to be one that I was really interested in. And it's not, I'm not excited by it any longer.

Like boredom, anxiety could interfere with interest and enjoyment. For these matureaged students, a lack of recent study experience, and therefore academic skills, was a common source of anxiety, particularly in relation to assessment. As past research has shown, high academic self-efficacy leads to enjoyment and enthusiasm whereas low self-efficacy can trigger boredom and frustration, inhibiting student engagement (Goetz, Frenzel, Hall, \& Pekrun, 2008). For instance, Melissa was passionately interested in the course content but her frustration caused by a lack of knowledge and understanding of the university grading systems, and an excessive focus on academic writing, overrode her passion:

Melissa: I find I'm getting so consumed by the technicalities that the actual reason for being there to like learn and have an understanding of the subject sort of gets pushed aside. ${ }^{3}$

At the extreme, these negative emotional responses to courses can lead to the ultimate disengagement, withdrawal: "It was just frustrating me too much... I thought, you know what? I can do without this. It's making me feel crap about studying" (Sarah).

\section{Belonging}

The second type of emotional engagement, belonging, was less evident in the students' talk. They rarely, if ever, spoke about a sense of connection to the institution, discipline, or course. The only exceptions were a student saying that getting welcome emails made them "feel like you're connected to, part of something" (Maria), and a second who commented on the impact of attending a campus-based class as part of their course:

Vee: I am glad I attended the contact course, it made me feel connected, like I am part of something. Or maybe finally I feel a sense of belonging in my new environment.

The students did not generally bemoan the lack of such connection however. In contrast, connections with their fellow students were important for most students. Face-to-face contact on campus-based courses was the most valued means of connecting for some students. However, not all courses offered this option and some students could not attend or did not want to attend. For those that did, the main benefit was the appreciation that other students were also struggling, which reduced the sense of isolation that distance students can feel.

Natasha: What I found the best was actually talking with the other students... the best thing for me to hear was that I wasn't the only one that was not coping (laughs)

Toni: That's what happened in the contact course. I think we were all looking at one another, oh yeah, you're doing this too. Oh geeze, you know, you're not so alone. Whereas being here, you are alone basically.

${ }^{3}$ For a full case study of Melissa's experiences, see Kahu (2013b).

50 | The International J ournal of the First Year in Higher Education, 5(2) August, 2014 
The online discussion forums provided an alternative way of connecting with other students, but different students experienced the forums very differently. On the one hand, for some students, as with the campus courses, the forums allowed them to know there were other "people like me" (Penny) and this made them more comfortable. Also, when faced with assessment tasks, questions from other students made some people feel better about their own difficulties: "It helps to know that I'm not the only one that's having trouble with certain things" (Jeremiah).

On the other hand, some students did not like the forums and felt they were "not as connected as being in a personal group with people" (Hollie). For some, fear of being negatively judged, particularly because they were older, inhibited them from participating. Comparisons with other students were also not always beneficial, with Natasha's experiences highlighting that the impressions gained from discussion forums do not necessarily reflect reality:

Natasha: [In the forum] people who were always very upbeat and oo I've done this and ooo I've done that and you're thinking, I'm screwed...When actually, when you meet people at the course, you realise that, no, we're all behind (laughs).

The potential isolation and lack of connection is a risk of distance study that the students were aware of before they commenced the semester. For some students they did not expect it to be a problem, they were happy to be independent learners: "I'm an introvert anyway, so I'm quite happy with my own company" (Maria). For other students such as Samantha it proved to be a substantial barrier to learning:
Samantha: The hardest thing, like I've said all along is the fact that I don't have anybody to discuss things with and go and have coffees. Somebody on the same wavelength as you and sort of ping-pong those ideas off one another and seeing if you're sort of feeling like you're on the same track. I know that you've got the websites and things like that but it doesn't feel the same for me.

Here Samantha highlights that connection with other students is important not just for a sense of empathy and to help relieve one's own anxiety, it is also valuable for discussing the course content. This is where the two forms of emotional engagement can link - interest is supported and fostered through discussions with other students about course content. One student, Daniel, was frustrated that the discussion forums on his course were not used more for this. He tried to stimulate such conversation by posting a comment about a media item that was relevant to the unit of study but only the tutor responded.

At times, staff played a role in mitigating the sense of isolation and helping students feel more connected. For instance, Samantha commented: "The tutors have been really good with the fact that they have said I can ring them any time and not to feel isolated". Nonetheless, the physical separation made a sense of connection too difficult for some. Toni explains why she would prefer face-toface learning:

Toni: Just that it makes me actually part of it, whereas the study by distance you're sort of, you've got it there and it feels as though you are missing something because the rest of it is somewhere else... Like the teacher is somewhere else.

For these mature-aged distance students, the most important element of emotional engagement was interest, their connection 
to the course content. It triggered behavioural and cognitive engagement and led to a positive spiral of enjoyment and satisfaction in their learning. Negative emotions such as boredom, frustration, and anxiety could inhibit students' interest. These emotions were triggered by course design and content as well as the student's skill set and self-efficacy. Regarding belonging, the second key element of emotional engagement, while students did not feel connected to the university or wider structures, connections with other students were important and desirable for most students. Face-to-face contact was invaluable for some while others were content with the online forums. For some students however, the lack of connection led to them rejecting distance study.

\section{Implications for practice}

The findings of this study have several implications for teachers of first year students. Firstly, in designing and delivering course curricula, educators need to continually look for ways of connecting the student with the material. Interest creates enthusiasm for the tasks at hand and results in students committing more time and energy as well as more in depth learning. Interest is triggered by connections the student can make with their own past experiences and future goals. While the benefits of work integrated learning are widely recognised in higher education (Patrick et al., 2008), the findings here suggest that this may be better conceptualised as life integrated learning, acknowledging that work is not the only way that students can connect with course content. Strategies for fostering interest include enabling topic choice for assessments, linking content to current media events, and triggering discussion in online forums. Mature-aged students have much to offer such discussions and giving structured opportunities to share relevant experiences can not only connect those students but also offer insights into the "real world" for younger students. It is not enough to provide the digital space however, past studies have highlighted the critical role that staff play in guiding and facilitating such discussions (TallentRunnels et al., 2006).

Discussion forums are not only valuable for connecting students to the course material, they are also useful for connecting students with each other, particularly first year students who have no experience at forging their own connections in this new environment. Similar to Kember, Lee, and Li (2001), who found that part time students affiliated more with their class groups than with the university, for these mature-aged students student-student connections were the most prevalent and, arguably, the most important. For some students in this study, online connection was not as effective as face-to-face, but for many it was better than no contact. As Bird and Morgan (2003) point out, the opportunity to alleviate one's fears and worries through benchmarking, comparison with other students, is limited for distance students. And, as Natasha experienced in this research, struggling students do not necessarily feel comfortable sharing with the entire class online. Again, staff participation in discussion forums can be helpful - openly acknowledging that there will be students who are struggling and who are worried can give space for those students to express their experiences. It could be useful too, to remind students that anxiety is normal, particularly for first year students, and that, as other findings from this project highlight, it can serve a valuable function in motivating behavioural engagement (Kahu, Stephens, Leach, \& Zepke, in press). 
However, as Self Determination Theory highlights, different students have different levels of need for autonomy, competence, and relatedness (Deci \& Ryan, 2000). Not all students want or need participation in discussion forums as LaPointe and Reisetter (2008) found out in their study. They highlight the importance of providing choice rather than making online peer connection compulsory.

A final important message for staff is the importance of maintaining awareness of all students' emotions more generally. Findings from this and other research highlight the emotional intensity and variability of students' first year at university (Christie et al., 2008). In particular, the power of frustration to reduce interest and disengage students is noteworthy. Maintaining high teaching standards is therefore critical: welldesigned course materials; avoiding excessive workload; transparent and fair assessment practices; clear and consistent instructions; and thoughtful balanced feedback are all ways of reducing student frustration. In particular, first year students are often unaware of university practices and standards so access to information is vital, while balancing the risk of overloading the students.

\section{Conclusion}

Emotional engagement is vital for first year students and yet is rarely explicitly considered in course design and delivery. Interest leads to persistence and a deeper approach to learning, while belonging helps to alleviate the commonly experienced anxiety. There is much that staff can do to facilitate students' connection to both course materials and their fellow students. In particular, discussion forums are useful tools in distance study although staff need to actively participate and not all students will want to participate. While this research looked specifically at mature-aged distance students, these recommendations are likely to benefit others as well.

\section{References}

Ainley, M. (2006). Connecting with learning: Motivation, affect and cognition in interest processes. Educational Psychology Review, 18(4), 391-405. doi: 10.1007/s10648-006-9033-0

Australian Council for Educational Research. (2010). Doing more for learning: Enhancing engagement and outcomes. Camberwell, Australia: Author.

Bird, J., \& Morgan, C. (2003). Adults contemplating university study at a distance: Issues, themes and concerns. International Review of Research in Open and Distance Learning, 4(1), 1-15. Retrieved from http://www.irrodl.org/

Braun, V., \& Clarke, V. (2006). Using thematic analysis in psychology. Qualitative Research in Psychology, 3, 77-101. doi: 10.1191/1478088706qp063oa

Christie, H., Munro, M., \& Wager, F. (2005). "Day students" in higher education: Widening access students and successful transitions to university life. International Studies in Sociology of Education, 15(1), 3-30. doi: 10.1080/09620210500200129

Christie, H., Tett, L., Cree, V. E., Hounsell, J., \& McCune, V. (2008). "A real rollercoaster of confidence and emotions": Learning to be a university student. Studies in Higher Education, 33(5), 567-581. doi: 10.1080/03075070802373040

Deci, E., \& Ryan, R. (2000). The "what" and "why" of goal pursuits: Human needs and the selfdetermination of behavior. Psychological Inquiry, 11(4), 227-268. doi: 10.1207/S15327965PLI1104_01

DiBiase, D., \& Kidwai, K. (2010). Wasted on the young? Comparing the performance and attitudes of younger and older US adults in an online class on geographic information. Journal of Geography in Higher Education, 34(3), 299-326. doi: 10.1080/03098265.2010.490906

Dirkx, J. (2006). Engaging emotions in adult learning: A Jungian perspective on emotion and transformative learning. New Directions for Adult and Continuing Education, 2006(109), 1526. doi: 10.1002 /ace.204 
Gallacher, J., Crossan, B., Field, J., \& Merrill, B. (2002). Learning careers and the social space: Exploring the fragile identities of adult returners in the new further education. International Journal of Lifelong Education, 21(6), 493-509. doi: $10.1080 / 0260137022000016172$

Goetz, T., Frenzel, A., Hall, N., \& Pekrun, R. (2008). Antecedents of academic emotions: Testing the internal/external frame of reference model for academic enjoyment. Contemporary Educational Psychology, 33(1), 9-33. doi: 10.1016/j.cedpsych.2006.12.002

Hoskins, S., \& Hooff, J. (2005). Motivation and ability: Which students use online learning and what influence does it have on their achievement? British Journal of Educational Technology, 36(2), 177-192. doi: 10.1111/j.14678535.2005.00451.x

Johnson, G., \& Watson, G. (2004). “Oh gawd, how am I going to fit into this?": Producing [mature] firstyear student identity. Language and Education, $18(6)$ 474-487. $10.1080 / 09500780408666896$

Kahu, E. (2013a). Framing student engagement in higher education. Studies in Higher Education, 38(5), 758-773. doi 10.1080/03075079.2011.598505

Kahu, E. (2013b). From "loving it" to "freaking out" and back again: The engagement of a mature distance student in their first semester at university. Refereed proceedings of the Manawatu Doctoral Research Symposium, 2, 5966. Retrieved from http://mro.massey.ac.nz/10179/2645

Kahu, E., Stephens, C., Leach, L., \& Zepke, N. (2013). The engagement of mature distance students. Higher Education Research and Development, 32(5), 791-804. doi: 10.1080/07294360.2013.777036

Kahu, E., Stephens, C., Leach, L., \& Zepke, N. (in press). Linking academic emotions and student engagement: Mature-aged distance students transition to university. Journal of Further and Higher Education.

Kasworm, C. (2010). Adult learners in a research university: Negotiating undergraduate student identity. Adult Education Quarterly, 60(2), 143160. doi: 10.1177/0741713609336110

Ke, F., \& Xie, K. (2009). Toward deep learning for adult students in online courses. The Internet and Higher Education, 12(3-4), 136-145. doi: 10.1016/j.iheduc.2009.08.001

Kember, D., Lee, K., \& Li, N. (2001). Cultivating a sense of belonging in part-time students. International
Journal of Lifelong Education, 20(4), 326-341. doi: 10.1080/02601370117754

Kuh, G. (2009). What student affairs professionals need to know about student engagement. Journal of College Student Development, 50(6), 683-706. doi: 10.1353/csd.0.0099

LaPointe, L., \& Reisetter, M. (2008). Belonging online: Students' perceptions of the value and efficacy of an online learning community. International Journal on E-Learning, 7(4), 641-665. Retrieved from http://www.aace.org/pubs/ijel/

Leder, G., \& Forgasz, H. (2004). Australian and international mature students: The daily challenges. Higher Education Research and Development, 23(2), 183-198. doi: 10.1080/0729436042000206654

Linnenbrink, E. (2006). Emotion research in education: Theoretical and methodological perspectives on the integration of affect, motivation, and cognition. Educational Psychology Review, 18(4), 307-314. doi: 10.1007/s10648-006-9028-x

Lundberg, C. (2003). The influence of time-limitations, faculty, and peer relationships on adult student learning: A causal model. The Journal of Higher Education, 74(6), 665-689. doi: $10.1353 /$ jhe.2003.0045

Marandet, E., \& Wainwright, E. (2009). Invisible experiences: Understanding the choices and needs of university students with dependent children. British Educational Research Journal, 36(5), 787-805. doi: 10.1080/01411920903165595

Mingers, J. (2004). Re-establishing the real: Critical realism and information systems. In J. Mingers \& L. Willcocks (Eds.), Social theory and philosophy for information systems (pp. 372-406). Chichester, United Kingdom: Wiley and Sons.

Ministry of Education. (2013). Education counts. Retrieved from http://www.educationcounts.govt.nz/statistics tertiary education

Patrick, C., Peach, D., Pocknee, C., Webb, F., Fletcher, M., \& Pretto, G. (2008). The WIL (Work Integrated Learning) report: A national scoping study [Australian Learning and Teaching Council (ALTC) Final report]. Brisbane, Australia: Queensland University of Technology. Retrieved from www.altc.edu.au

Pekrun, R., \& Linnenbrink-Garcia, L. (2012). Academic emotions and student engagement. In $S$. Christenson, A. Reschly, \& C. Wylie (Eds.), Handbook of research on student engagement (pp. 259-282). New York, NY: Springer.

54 | The International J ournal of the First Year in Higher Education, 5(2) August, 2014 
Rovai, A. (2002). Building a sense of community at a distance. International Review of Research in Open and Distance Learning, 3(1). Retrieved from http://www.irrodl.org

Sayer, A. (2000). Realism and social science. London, United Kingdom: Sage.

Silvia, P. (2006). Exploring the psychology of interest. New York, NY: Oxford University Press.

Tallent-Runnels, M., Thomas, J., Lan, W., Cooper, S., Ahern, T., Shaw, S., \& Liu, X. (2006). Teaching courses online: A review of the research. Review of Educational Research, 76(1), 93-135. doi: 10.3102/00346543076001093

Thomas, L. (2012). Building student engagement and belonging in higher education at a time of change: Final report from the What Works? student retention and success programme. London, United Kingdom: Higher Education Funding Council for England.

Tinto, V. (1975). Dropout from higher education: A theoretical synthesis of recent research. Review of Educational Research, 45(1), 89-125. doi: 10.3102/00346543045001089

Trowler, V., \& Trowler, P. (2010). Student engagement evidence summary. York, United Kingdom: The Higher Education Academy.

Wyatt, L. (2011). Nontraditional student engagement: Increasing adult student success and retention. The Journal of Continuing Higher Education, 59(1), 10-20.

doi: 10.1080/07377363.2011.544977

The International J ournal of the First Year in Higher Education, 5(2) August, $2014 \mid 55$ 